\title{
PEMAKAIAN AKROLEK PADA TINDAK TUTUR ASERTIF DALAM SINIAR DEDDY CORBUZIER
}

\author{
Nurliawati Dide ${ }^{1)}$, Gigit Mujianto ${ }^{2)}$ \\ ${ }^{12}$ FKIP, Universitas Muhammadiyah Malang \\ Pos-el: didewatiy@gmail.com, gigit@umm.ac.id
}

\begin{abstract}
Abstrak
Tujuan dalam penelitian ini yaitu untuk mengetahui ciri dari pola tutur variasi akrolek, bentuk fungsi tuturan asertif, dan hubungan ciri pola tutur variasi akrolek pada bentuk fungsi tindak tutur asertif dalam siniar Deddy Corbuzier. Penelitian ini merupakan penelitian kualitatif. Sumber data penelitian adalah interaksi antara pembawa acara dan narasumber dalam siniar Deddy Corbuzier. Data yang digunakan yaitu kutipan percakapan antara pembawa acara dan narasumber yang mengandung variasi bahasa akrolek dan hubungannya dengan tindak tutur asertif. Teknik pengumpulan data menggunakan teknik observasi. Teknik analisis data menggunakan model Miles dan Huberman, yaitu melalui tahapan reduksi data, penyajian data, dan penarikan kesimpulan. Hasil penelitian ini menunjukkan: (1) ciri pola tutur variasi akrolek yang terdiri dari bahasa yang berkonotasi tinggi serta bergengsi dan tidak sesuai dengan kaidah bahasa Indonesia. (2) bentuk tuturan asertif yang terdiri dari tuturan asertif mengeluh, menyarankan, mengklaim, membanggakan, melaporkan, dan memberitahukan. (3) hubungan ciri pola tutur variasi akrolek pada bentuk fungsi tindak tutur asertif menciptakan suatu respon serta memberikan informasi berdasarkan kenyataan.

Kata kunci: tindak tutur, variasi akrolek, tindak tutur asertif.
\end{abstract}

\begin{abstract}
The purpose of this study is to find out the characteristics of the acrolectic variation of speech patterns, the form of assertive speech functions, and the relationship between the characteristics of the acrolectic variations of speech patterns in the form of assertive speech acts in Deddy Corbuzier's narration. This research is a qualitative research. The source of research data is the interaction between the presenter and the resource person in Deddy Corbuzier's broadcast. The data used are excerpts from conversations between the presenter and the resource person containing variations of acrolectic language and its relationship with assertive speech acts. Data collection techniques using observation techniques. The data analysis technique uses the Miles and Huberman model, namely through the stages of data reduction, data presentation, and drawing conclusions. The results of this study indicate: (1) the characteristics of the acrolectic variation of speech patterns which consist of languages that have high and prestigious connotations and are not in accordance with the rules of the Indonesian language. (2) the form of assertive speech consisting of assertive speech complaining, suggesting, claiming, boasting, reporting, and notifying. (3) the relationship between the characteristics of the acrolectic variation of speech patterns in the form of the function of assertive speech acts creates a response and provides information based on reality. Keywords: speech act, acrolec variation, assertive speech act.
\end{abstract}

Ciptaan disebarluaskan di bawah Lisensi Creative Commons Atribusi-BerbagiSerupa 4.0 Internasional Diterbitkan Oleh: https://ejournal.umpri.ac.id/index.php/pesona

Pesona: Jurnal Kajian Bahasa dan Sastra Indonesia 


\section{PENDAHULUAN}

Percakapan yang terjadi antara penutur dan mitra tutur tujuannya adalah saling berbagi infromasi. Setiap komunikasi yang terjalin tentunya memiliki maksud yang ingin disampaikan. Forum untuk berbagi informasi pun sering dilakukan. Walaupun dengan keadaan pandemi yang mengaharuskan untuk sementara tidak boleh bertemu secara langsung lewat tatap muka. Akan tetapi, ketika sudah mematuhi protokol kesehatan dengan jumlah batasan orang yang hadir maka tidak salahnya forum diskusi dibangun kembali dan memberikan ruang untuk para pembicara menyampaikan informasi yang sedang terjadi sehingga dapat berbagi dengan orang lain.

Media informasi lainnya selain TV adanya youtube yang saat ini sudah menjadi alat atau media untuk mengekspresikan diri dan memberikan pengalaman serta informasi yang dapat dijangkau oleh setiap orang. Forum yang membahas terkait diskusi salah satunya adalah siniar atau bahasa yang sering digunakan kalangan saat ini adalah podcast. Percakapan terkait politik, keuangan, sosial, agama, dan lain-lain sering dibahas dalam forum ini. Komunikasi yang terjalin tidak dalam kondisi yang resmi atau formal sehingga, banyak kosakata yang menggunakan bahasa sehari-hari atau bahasa yang bergengsi, bahasa yang tidak sesuai dengan kaidah bahasa Indonesia yang tepat.

Oleh karena itu, dengan adanya forum siniar ini, banyak hal yang bisa dijadikan pengalaman dan pelajaran hidup yang bisa dipetik. Selain itu, video adalah salah satu cara tercepat untuk terhubung dan membangun hubungan yang kuat dengan pelanggan, dan alasan mengapa video begitu viral adalah karena komunikasi non-verbal selama $90 \%$. (Wirga, 2016).

Komunikasi yang terjalin karena adanya bahasa maka manusia dapat memberikan serta menyampaikan gagasan dan pemikirannya sesuai dengan maksud dan tujuannya. Oleh karena itu, bahasa ada di dalam kehidupan manusia agar saling berinteraksi, mengerti dan saling belajar tuturan dari masing-masing (Prasasti \& Mujianto, 2020).

Percakapan adalah jenis peristiwa yang dibicarakan dalam kegiatan sosial karena berkaitan erat dengan pihak-pihak yang terlibat dalam kegiatan komunikasi pada waktu atau peristiwa tertentu. Pembicara ingin orang lain mengerti dan memahami informasi yang disampaikan pembicara. Oleh karena itu, penutur 
berinteraksi interaktif menggunakan strategi kontekstual berbasis masalah yang mudah dipahami lawan bicara Wijaya (dalam Apriastuti, 2017:40).

Penggunaan bahasa dalam kegiatan berbahasa merupakan kemampuan manusia yang tidak ada pada makhluk hidup lainnya. Kemampuan menggunakan bahasa menjadikan manusia dengan banyak budaya dan pengetahuan sosial dan moral serta meningkatkan kualitas sebagai ukuran kualitas. Penggunaan bahasa dalam kehidupan sehari-hari tidak berarti penggunaan behasa baku yang tepat dan tepat yang ditetapkan oleh pemerintah tetapi sesuai dengan praktik, fungsi, tujuan, dan konteks kegiatan lisan tertentu (Susilawati, 2017:1).

Masyarakat yang menggunakan ciriciri linguistik tidak terlepas dari linguistik yang digunakan untuk berkomunikasi. Bidang kajian bahasa yang digunakan masyarakat ditinjau dari fungsi dan keanekaragamannya yang disebut sosiolingustik. Fasold (dalam Saddhono, 2006:2-3) mengemukakan bahwa sosiolingustik didasarkan pada dua fakta. Peratama, keragaman bahasa tergantung pada pilihan bahasa penutur. Kedua, bahasa sebagai sarana atau alat untuk menyampaikan perasaan dan pemikiran penutur dalam cerita.
Fakta ini menyangkut penggunaan bahasa dalam hal perbedaan jenis kelamin, usia, kelas, sosial, hubungan antar penutur, tujuan komunikasi, dan tempat kemunikasi dalam kelompokkelompok atau komunitas tertentu (Mujianto, 2013:14). Tidak hanya itu, penggunaan bahasa pun berubah seiring berjalannya waktu. Seiring berjalan waktu, jenis variasi bhasa baru dapat terbentuk, termasuk variasi bahasa akrolek. Menurut Searle dan Agustin (dalam Nuryani, 2016:64), variasi bahasa akrolek merupakan jenis variasi yang paling tinggi dan bergengsi di antara bahasa-bahasa yang lainnya. Bahasa akrolek adalah bahasa yang sering digunakan oleh bagsawan dan abdi dalam sebagai raja atau masyarakat perkotaan. Hal ini sesuai dengan pendapat yang diberikan oleh Suhendar (2016:56) yaitu salah satu faktor yang menyebabkan variasi bahasa akrolek sejajar dengan bahasa lain adalah hipotesis mengenai nilai variasi bahasa akrolek.

Penggunaan variasi akrolek yang biasanya digunakan di kalangan masyarakat dalam situasi informal dan dalam bentuk yang dilakukan di kalangan pembicara stasiun TV Indonesia sangat beragam, media online youtube adalah salah satu media yang paling popular untuk ditonton. Ini karena media aplikasi 
youtube juga mencangkup acara pidato, percakapan, dan lainnya (Soyomukti, 2013:6). Salah satunya adalah acara siniar Deddy Corbuzier yang membahas masalah politik, sosial, keuangan, Kesehatan dan lainnya. Banyak aktor, politikus, dokter dan pembicara lainnya yang diundang sebagai narasumber dalam siniar tersebut. pembicaraan yang erat kaitannya dengan kenyataan, dan kemampuan berbicara asertif serta penggunaan variasi akrolek sering digunakan dalam percakapan tersebut.

Variasi bahasa merupakan sebuah bentuk pemakaian tuturan yang digunakan oleh masyarakat dengan berbagai perbedaan latar belakang sosial, budaya, tradisi, adat-istiadat, pendidikan, agama, dan perbedaan-perbedaan lainnya. Salah satunya adalah variasi bahasa akrolek yaitu variasi sosial yang dianggap lebih tinggi atau lebih bergengsi daripada variasi sosial lainnya (Searle dan Agustin, 2010: 66). Ciri-ciri variasi akrolek menurut Ismiyati (2011:17) antara lain: (1) bahasa yang berkonotasi tinggi dan bergengsi dengan dialek Jakarta dan bahasa metropolitan. (2) ungkapan sering kali tidak sesuai dengan kaidah bahasa kosakata yang digunakan seperti kata gue (saya), elu (kamu), nyokap (ibu), bokap (ayah), dan lain sebagainya.
Menurut Yule (dalam Tressyalina, 2015:92) aktivitas bertutur mempunyai hubungan langsung antara struktur dan fungsi tuturan yang disebut tuturan langsung. Akan tetapi, jika tidak mempunyai hubungan antara struktur dan fungsi maka disebut tuturan tidak langsung. Berdasarkan penjelasan tersebut, tuturan langsung menunjukkan persamaan antara bentuk dan modus tutur, sedangkan tuturan tidak langsung merepresentasikan perbedaan antara modus dan bentuk tutur yang digunakan oleh penutur.

Berbicara adalah kemampuan untuk menyampaikan pesan kepada orang lain melalui bahasa lisan. Aktivitas lisan di mana pembicara berinteraksi dapat dianggap sebagai percakapan dan dapat menjalin komunikasi. Fungsi asertif menurut Padmi (2017), yaitu: (1) menyampaikan sesuatu. (2) terkait kebenaran proposisi atau pernyataan yang diungkap.

Penggunaan ciri tutur asertif cenderung menggunakan variasi akrolek tutur dengan tujuan sebagai berikut menurut Prasasti \& Mujianto (2020), yaitu: (1) mencipta suatu respon. (2) Pemberi informasi berdasar realita atau kenyataan. 
Berpijak pada uraian di atas, penelitian ini berjudul "Analisis Pemakaian Akrolek Pada Tindak Tutur Asertif dalam Siniar Deddy Corbuzier". Berdasar judul tersebut penelitian bertujuan untuk menjelaskan penggunaan ciri pola variasi akrolek serta hubungannya dengan bentuk fungsi tuturan asertif dalam siniar Deddy Corbuzier. Fokus penelitian ini mengkaji ciri pola akrolek, bentuk fungsi tuturan asertif serta hubungannya antara ciri akrolek dan bentuk tuturan asertif.

Kajian ini menarik karena penggunaan bahasa asertif diharapkan dapat memajukan penelitian tentang perubahan bahasa akrolek di bidang sosiolingustik. Selain itu, adanya variasi dalam bahasa kelas menengah, karena bahasa kelas menengah diwakili. Berbagai jenis bahasa gaul atau akrolek, penggunaannya adalah bentuk ucapan yang tegas.

Selain itu, penelitian ini sudah pernah diteliti sebelumnya oleh Prasasti \& Mujianto (2020) akan tetapi fokusnya berbeda yaitu tentang variasi akrolek dengan tuturan asertif secara menyeluruh. Penelitian yang serupa lainnya diteliti oleh Apriyanti (2017) berjudul Tindak Tutur Asertif Penjual dan Pembeli di Pasar Tempel Rajabasa dan Bandar Lampung serta Implikasinya Pada
Pembelajaran Bahasa Indonesia di SMA. Objek penelitian yaitu di pasar Tempel Rajabasa dan Bandar Lampung membahas tentang ekspresif tindak tutur asertif antara penjual dan pembeli. Penelitian lainnya yaitu oleh Arnaselis (2017) yang berjudul Tindak Tutur Asertif dalam Roman Larasati Karya Pramoedya Ananta Toer dan Implikasinya. Objek penelitiannya yaitu pembelajaran Bahasa Indonesia di SMP tentang peimplikasian tuturan asertif.

Penelitian ini berbeda dengan penelitian sebelumnya yaitu, pada fokus penelitian yang mengangkat tentang siniar antara presenter dan narasumber. Selain itu, ditunjukkan adanya ciri pola varaisi akrolek, bentuk tuturan asertif, serta hubungannya ciri pola tutur variasi akrolek dari segi fungsinya.

Penelitian ini menggunakan pendekatan deskriptif untuk menjelaskan dan mengungkap peran teoretis dari karakteristik variasi akrolek dalam tuturan asertif presenter dan narasumber. Oleh karena itu, metode penelitian ini menggunakan analisis deskriptif. Sumber data penelitian berupa siniar youtube Deddy Corbuzier dengan beberapa topik seperti: (1) Peraturan Protokol terkait Talkshow, Realitishow, Podcast, dan Senetron Selama Kondisi Pandemi. (2) UU ITE. (3) Konspirasi Segitiga Dunia. 


\section{METODE PENELITIAN}

Metode pengumpulan data melalui survei dari beberapa video di media sosial youtube siniar Deddy Corbuzier. Kemudian kelompokkan untuk masingmasing data untuk dianalisis lebih lanjut. Analisis data dilakukan pada acara Deddy Corbuzier dengan menggabungkan rekaman berdasarkan metrik fungsi audio afirmatif antara presenter dan narasumber. Berdasarkan penelitian sebelumnya, data dalam penelitian ini dikumpulkan dengan cara transkip data dan digolongkan untuk dianalisis melalui model Allir (Huberman \& Milles, 1992). Analisis data model ini terdiri dari tiga tahapan yakni, mengumpulkan data, (2) pemilihan data, (3) penjelasan data, dan (4) pengambilan kesimpulan.

\section{HASIL DAN PEMBAHASAN}

Hasil penelitian dari siniar Deddy Corbizier menemukan ciri-ciri variasi akrolek yaitu: (1) bahasa yang berkonotasi tinggi dan bergengsi, dan (2) ungkapan tidak sesuai dengan kaidah bahasa Indonesia. Selain itu, ditemukan adanya bentuk tuturan asertif yaitu: (1) asertif menyatakan, (2) asertif mengeluh, (3) asertif menyarankan, (4) asertif mengklaim, (5) asertif membanggakan, (6) asertif melaporkan, dan (7) asertif memberitahukan. Serta hubungan ciri pola tutur variasi akrolek pada bentuk fungsi tindak tutur asertif, yaitu: (1) mempunyai maksud dn tujuan serta (2) keterlibatan narasumber.

\section{Ciri Tuturan Variasi Akrolek dalam Siniar Deddy Corbuzier}

Pada ciri pola variasi akrolek terdapat beberapa ciri di antaranya bahasa yang berkonotasi tinggi dan bergengsi serta ungkapan sering kali tidak sesuai dengan kaidah bahasa dapat dideskripsikan pada data sebagai berikut.

\section{Bahasa yang berkonotasi tinggi dan bergengsi}

Bahasa yang berkonotasi tinggi dan bergengsi adalah bahasa yang digunakan terkadang menggunakan gabungan bahasa asing dan bahasa Indonesia. Contohnya seperti kota metropolitan. Sebab para remaja di daerah, dan yang pernah ke Jakarta, merasa bangga bisa berbicara dengan dialek Jakarta dan bahasa metropolitan. Kata yang sering dituturkan seperti: bebh, gak usah drama deh, gue lapar, jangan buat gue naik darah.

Data 1

Narasumber: "Trus kalo lo udah tau jawabanya kenapa lo tanya ke gua?" (dengan ekspresi tatapan tajam kepada presenter) 
Presenter : "nggak ini kan baru”

Peristiwa tersebut terjadi ketika presenter menampilkan tampilan gambar beberapa acara TV di luar negeri yang menggunakan facial mask dan terdapat deskripsi kecil pada bagian bawah TV bahwa acara nya terjadi pada saat kondisi covid-19. Tuturan yang disampaikan oleh narasumber pada acara siniar tersebut terdapat bahasa yang diajukan dengan nada tinggi yaitu pada kalimat.

Hal ini merupakan bentuk pertanyaan yang diberikan oleh narasumber dengan terselip bahasa akrolek. Narasumber mempertanyakan kembali kepada presenter tentang tampilan yang disajikan. Karena jika dilihat pada kalimat tersebut ekspresi narasumber kepada presenter terlihat tegang dan marah dengan tekanan nada yang tinggi pada bagian akhir kalimat yaitu kenapa lo tanya ke gua?. Narasumber merasa jika presenter sudah mengetahuinya dengan penjelasan maka hal tersebut tidak perlu untuk dipertanyakan kepada narasumber. Sehingga terlihat tanggapan yang diberikan oleh presenter dengan menutupi kesalahan tersebut bahwa presenter mengatakan tampilan gambar yang diambil adalah peristiwa yang baru terjadi. Oleh karena itu, pada data 1 termasuk ke dalam variasi akrolek. Hal ini sejalan dengan pendapat Chaer dan Agustina (dalam Susilawati \& Yunus, 2017) yaitu variasi bahasa yang dianggap lebih tinggi dibandingkan dengan variasi bahasa lainnya.

$$
\text { Pada data (2) peristiwa presenter }
$$
sedang mengungkapan bagaimana dirinya menjadi orang sedang rostting dari pelawak atau seorang komedian. Kata rostting yaitu menyampaikan kejelekan atau kelemahan yang dimiliki orang yang menjadi objek tersebut untuk digunakan sebagai bahan komedi. Hal ini bisa dilihat pada kutipan berikut.

Data 2

Presenter: "Sering ngejokes sama gua gua lagi dayanya jalur nutrisi ketawa tapi ketika misalnya lu ketemu gue nih gue sering ketemu gue terus lu ngomong gua botak nih nyisirannya susah nih. Lu segitu doang nih jadi aneh nggak lucu lagi gitu"

Pada data (2), penyampaian dari presenter dengan mencerikan kisah nya kepada narasumber tentang rostting (sebuah kegiatan melihat kelemahan seseorang, kemudian dijadikan bahan komedi, dengan persetujuan yang sudah ditentukan). Kisah yang disampaikan presenter menunjukkan adanya bahasa atau dialek Jakarta yang digunakan, karena adanya kalimat Lu segitu doang nih jadi aneh nggak lucu lagi gitu. Kata lu dan nggak, yang menunjukkan ciri dari 
bahasa metropolitan. Dengan demikian hal ini sesuai dengan teori dari Ismiyati (2011:17) yaitu Bahasa yang berkonotasi tinggi dan bergengsi karena dialek Jakarta adalah sebuah dialek yang dilakukan atau bahasa yang dituturkan sehari-hari untuk memberikan kesan gengsi.

\section{Ungkapan tidak sesuai dengan kaidah bahasa}

Ungkapan tidak sesuai dengan kaidah bahasa Indonesia adalah penutur dan mitra tutur tidak menggunakan bahasa Indonesia yang tepat pada saat berbicara. Contohnya: gue laper.

Presenter: "Gimana dong? Yang bener aja tanya gua Kenapa tanya gua ара gua petugas satgas ya?"

Narasumber: "Elu mau cekek-cekekan pakai masker?"

Berdasarkan data di atas, terlihat kata-kata yang digunakan yaitu menggunakan kosa kata Yang bener aja tanya gua kenapa tanya gua apa gua petugas satgas ya? Kata gua yang tidak sesuai dengan kaidah bahasa Indonesia dan kata bener yang harusnya pelafalan yang tepat adalah benar. Begitupun dengan respon yang diberikan oleh narasumber yaitu kata Elu yang pada padanan yang benar dalam bahasa Indonesia adalah kamu. Tuturan yang diberikan oleh narasumber dan presenter menggunakan dialek Jakarta yang gaya berbicaranya tidak sesuai dengan padanan dalam bahasa Indonesia yang tepat.

Pada ciri tutur variasi akrolek ditemukan adanya variasi akrolek, kata dialek Jakarta cenderung lebih bergengsi sebagai salah satu ciri kota metropolitan, sebab para remaja di daerah, dan yang pernah ke Jakarta, merasa bangga bisa berbicara dengan dialek Jakarta itu. Di mana Akrolek adalah variasi bahasa yang dianggap lebih tinggi atau lebih bergengsi daripada variasi sosial lainnya. Chaer dan Agustina, (2010: 66).

Pada penelitian sebelumnya oleh Nuryani et al., (2018) dengan judul Variasi Bahasa Pada Pementasan Drama Cipoa dan Sidang Para Setan Mahasiswa Pendidikan Bahasa dan Sastra Indonesia Tahun 2017. Ciri variasi akrolek yang dihasilkan dalam penelitian tersebut tidak jauh berbeda dengan penelitian ini. Pada penelitian sebelumnya ditemukan adanya varaisi bahasa akrolek yang menggunakan gabungan bahasa Indonesia dengan bahasa asing (bahasa inggris). Hasil penelitian yang lainnya yaitu sudah menggabungkan bahasa Inggris dengan bahasa Indonesia yang padanan katanya pun tidak sesui dengan kaidah. Penggunaan beberapa bahasa di masyarakat dipandang sebagai upaya 
menjembatani kesenjangan antara menjalin komunikasi yang baik dengan menjalin keakraban dan pemahaman antar penutur.

Dengan demikian, penyampaian antara penutur dan mitra tutur menggunakan bahasa metropolitan tidak sesuai dengan kaidah bahasa Indonesia sehingga dapat disimpulkan bahwa bahasa metropolitan yang menggunakan bahasa inggris pun termasuk ke dalam variasi bahasa akrolek.

\section{Bentuk Fungsi Tuturan Asertif}

Fungsi bahasa yang termasuk ke dalam jenis ilokusi menurut Searle (dalam Rachman, 2015:2-5) dapat dikategorikan ke dalam berbagai bentuk fungsi meliputi: tuturan asertif menyatakan, mengeluh, menyarankan, mengklaim, membanggakan, melaporkan, memberitahukan, dan membual. Penggunakaan tindak tutur aserif dapat ditemukan dalam kehidupan sehari-hari, seperti komunikasi yang terjalin antarmanusia.

\section{Tuturan Asertif Menyatakan}

Tuturan asertif menyatakan adalah tuturan yang ingin disampaikan oleh penutur kepada mitra tutur dengan maksud dan tujuan tertentu.
Pada data yang ditemukan, tuturan "Gua terus terang aja, gua jawab karena ITE ini adalah taci subject terutama buat comedian" hal yang diungkapkan narasumber pada siniar tersebut membuktikan bahwa tuturan tersebut merupakan tuturan menyatakan, karena terdapat informasi yang ingin disampaikan oleh pihak tutur kepada penutur. Dapat dilihat pada kutipan berikut.

Presenter: "ITE kan mau dirubah katanya, gimana pendapat anda stujukah untuk di rubah?"

Narasumber: "Gua terus terang aja, gua jawab karena ITE ini adalah taci subject terutama buat komedian karena yang paling rentan kena ITE sebenarnya selain seluruh masyarakat Indonesia tentunya komedian karena sebenarnya sih permasalahannya gini om, gua belum tahu apa yang nanti bagian poin-poin mana yang akan dirubah terus terang gue belum tau"

Selain itu, terdapat kata Gua terus terang aja, gua jawab ini merupakan bukti yang ditandai dengan adanya tuturan menyatakan dari narasumber. Secara langsung narasumber ingin menyatakan bahwa komedian adalah orang yang rentan terkena UU ITE karena dengan bahasa komedian yang frontal dan secara terbuka membuat tuturan yang disampaikan kadang-kadang melanggar 
dengan hukum yang ada. Narasumber juga mengatakan bahwa dia tidak tahu bagian mana yang akan diubah dari pasal UU ITE. Hal tersebut secara langsung dituturkan oleh penutur.

\section{Tuturan Asertif Mengeluh}

Tuturan asertif mengeluh adalah tuturan yang disampaikan dengan keadaan sedih

Narasumber: "gini Pak Agung nggak enakan gini nih kita lihat ada orang bilang punya antibodi sendiri dia katanya dia penganut konspirasi fotonya juga Nggak pakai kebal Padahal Candra bilang Kalau Om Dedi susah banget karena dia punya protokol kesehatan sendiri TNS"

Pernyataan mengeluh dari Candra yang mengatakan bahwa Om Deddy itu sangat susah jika diajak untuk syuting atau berkolaborasi karena protokol yang diminta sangatlah sulit dan harus terpenuhi. Hal ini diungkapkan kepada salah satu narasumber.

Persyaratan yang diberikan adalah untuk menjaga dirinya dari virus agar bisa terhindar dan tidak rentan terkena. Oleh karena itu, dibutuhkan adanya protokol Kesehatan yang memadai agar proses syuting yang dijalankan dapat dilakukan tanpa harus khawatir. Dengan demikian tuturan Dedi susah banget karena dia punya protokol kesehatan sendiri TNS tersebut termasuk ke dalam tuturan mengeluh.

\section{Tuturan Asertif Menyarankan}

Tuturan asertif menyarankan, yaitu ketika seseorang memberikan saran serta sebagai solusi dalam upaya meningkatkan keteraturan.

Narasumber: "Nah malah ada usul begini Om Dedy kalau bisa begini Om Dedi ini ada apa tanda silang tanda silang di usulan gitu Satgas jadi panggung itu udah ada tanda silang"

Kalimat tersebut termasuk ke dalam bentuk tuturan menyarakan karena pada awal kalimat sudah mengatakan kata ada usul hal tersebut sudah jelas bahwa tuturan tersebut termasuk ke dalam tuturan menyarankan yang diberikan oleh narasumber kemudian disampaikan dalam siniar. Narasumber mengusulkan untuk diadakannya tanda silang pada panggung di setiap acara TV agar mempermudah untuk menjaga jarak dan sesuai dengan protokol kesehatan yang berlaku.

\section{Tuturan Asertif Mengklaim}

Tuturan asertif mengklaim adalah tuturan yang menyetujui pendapat.

Presenter: "Bukan, ini saya mengatakan orangorang yang ngomong"

Tuturan presenter kepada narasumber mengklaim bahwa pernyataan 
yang diberikan ini adalah untuk orangorang yang berbicara terkait dengan protokol kesehatan bukan untuk pembelaan kepada masyarakat bahwa ini adalah acara TV yang menayangkan edukasi dan ini yang bukan. Tidak seperti itu, sehingga antara TV satu dengan TV yang lainnya tidak saling memberikan statement siapa yang lebih baik, namun melihat siapa orang di balik pembicaraan tersebut.

\section{Tuturan Asertif Membanggakan}

Tuturan asertif membanggakan, yaitu tuturan yang berisi pujian kepada orang lain.

Presenter: "pertanyaan saya adalah lah kan mungkin penonton Indonesia kan sekarang juga sudah mulai pintar Mas Agung ya maksudnya juga sudah tahu proses itu sudah kita lakukan"

Pada data (1), pernyataan yang diberikan oleh presenter yaitu tuturannya mengatakan bahwa dia bangga dengan masyarakan Indonesia yang sudah mulai pintar melihat situasi yang ada. Oleh karena itu, sekarang dengan visual yang ditampilkan saja, para penikmat sudah mulai mengerti kesimpulan dan informasi yang ditayangkan. Dengan demikian tontonan yang harus ditayangkan oleh TV harus sudah masuk ke dalam tahap lulus dari penyaringan dan lulus uji kelayakan untuk ditayangkan agar hal-hal buruk tidak akan terjadi.

\section{Tuturan Asertif Melaporkan}

Tuturan asertif melaporkan, tuturan yang terdapat laporan dan informasi untuk diberitahukan kepada orang lain.

Narasumber: "formula yang pertama ini Mungkin Bisa dicek dan dari podcast sebelumnya pun aku udah bilang untuk talkshow selama semua $\mathrm{pH}$ dan stasiun TV menandatangani Pakta bersama untuk melaporkan skrining terus-terusan jadi kayak kayak gini. Kayak pabrik di Karawang itu rata-rata mereka tiap bulan ke laporan kayak, bulan ini yang swab antigen berapa yang positif berapa”

Pada data tersebut tuturan yang disampaikan oleh narasumber. narasumber mendapatkan laporan serta meminta para crew untuk melakukan skrining secara terus menerus serta hasil akan diupdate setiap harinya demi untuk menjaga kebersamaan. Hal ini dilakukan dan diminta oleh narasumber agar pada saat di lapangan tidak ada kekhawatiran karena semuanya sudah aman dan masuk ke tahap pengecekan protokol kesehatan ini untuk syuting layar lebar dan sinetro. 
Banyak anggota yang terlibat langsung di lapangan untuk saling berkomunikasi maka tahap ini harus masuk ke dalam model karantina dan pemain maupun crew tidak boleh keluar dari lokasi tersebut sebelum selesai dalam proses syuting yang panjang.

\section{Tuturan Asertif Memberitahukan}

Tuturan asertif memberitahukan, yaitu tuturan dengan maksud untuk menyampikan informasi. Pada data yang ditemukan, sebagai narasumber beliau memberitahukan bahwa lebih baik melihat titik fokus permasalahannya tuturan bukan untuk melihat dari sisi latar belakang Ridwan Remin.

Narasumber: "Daripada kita hemer jadi menurut gue gini semua headspeed yang ada di sosial media itu adalah akibat kita lebih interest menyerang akibatnya dari pada tarik ke belakang apa sebabnya"

Karena Ridwan yang memulai semua ini, maka harus dilihat dari tuturan yang diucapakan sehingga menimbulkan titik terang dan ujung dari permasalahan. Akan tetapi, karena ini sudah masuk ke ranah umum maka, semuanya menjadi lebih luas.

Pada penelitian sebelumnya terdapat hal yang sama yaitu penelitian oleh Prasasti \& Mujianto, (2020) Tindak tutur menyatakan dilakukan oleh penutur pendidikan untuk menyatakan suatu informasi berdasar fakta yang disertai dengan kata permohonan maaf. Hal yang membedakannya dengan penelitian saat ini adalah menggunakan penanda kalimat Gua terus terang aja yang memberikan tanda bahwa penutur ingin menyatakan sesuatu informasi yang dirasakan selama ini dengan berprofesi sebagai seorang komedian. Sebagai salah satu contoh pada data. Kemudian pada penelitian yang sebelumnya ditemukkan adanya terdapat beberapa tuturan di antaranya (1) tuturan asertif; (2) tuturan asertif membual; (3) tuturan asertif menyaran; (4) tuturan asertif mengeluh.

Perbedaan dengan penelitian sebelumnya tuturan memberitahukan bahwa harus berhati-hati dan didukung beberapa pernyataan dengan menyarankan bentuk lain. Sedangkan dalam penelitian saat ini tuturan memberitahukan yang dimaksud adalah penutur memberitahukan bahwa media sosial sangatlah menarik dan mengundang banyak perdebatan dan permasalahan. Karena satu perkataan yang salah maka akan mengundang komentar yang tidak baik bahakan negatif oleh para responden media sosial. 
Perbedaan yang lainnya pada penelitian saat ini adalah penutur menunjukkan mitra tutur harus mengetahui fakta yang terjadi di lapangan seperti apa dan ditindaklanjuti sehingga masalah tidah berlarut-larut terjalin terus menerus. Hal tersebut sejalan dengan pendapat yang disampaikan Safriani et al., (2018) bahwa pada tuturan mengklaim yang disampaikan mitra tutur memiliki maksud untuk menyetujui pendapat dari penutur. Jadi, terdapat bentuk klaim yang terjadi dengan maksud dan tujuan yang berbeda-beda.

Tuturan yang disampaikan narasumber kepada preseter secara langsung menyatakan tentang pendapatnya terkait permasalahan komedian. Hal ini sependapat dengan Prasasti \& Mujianto, (2020) menyatakan bahwa strategi tuturan langsung literal diindikasi dari perasaan yang sama dengan kata-kata penyusunnya yaitu kalimat menyatakan.

Bahasa yang digunakan dalam berkomunikasi. Berdasarkan hasil penelitian ini, antar presenter dan narasumber menggunakan fungsi suara asertif seperti: (1) tuturan asertif menyatakan maaf, terima kasih, dan tuturan menyatakan suatu informasi; (2) tuturan asertif mengeluh, menghadirkan sebuah presepsi negatif dan ungkapan perasaan kecewa dan sedih dengan keadaan yang ada atau keadaan yang tidak sesuai dengan rencana; (3) tuturan asertif menyarankan, penutur menyampaikan langsung informasi yang dapat mengembalikan situasi yang lebih baik dengan dibantu beberapa hal pendukung; (4) tuturan asertif mengkalim, digunakan penutur untuk menguatkan pendapat dengan memberikan beberapa informasi yang teraktual sesuai dengan fakta; (5) tuturan membanggakan, ungkapan terima kasih, waktu yang diluangkan, hal-hal kecil yang diperhatikan oleh mitra tutur ke penutur; (6) tuturan asertif melaporkan, memberitahukan fakta yang sesuai, dan informasi yang ditemukan; (7) tuturan asertif memberitahukan, menginformasikan hal yang belum dikatahui oleh mitra tutur.

\section{Hubungan Ciri Pola Tutur Variasi} Akrolek Pada Bentuk Fungsi Tindak Tutur Asertif

Fungsi asertif adalah menyampaikan sesuatu dan adanya terkait kebenaran proposisi atau pernyataan yang diungkap.

\section{Mempunyai Maksud dan Tujuan}

Tuturan yang disampaikan oleh penutur dan mitra tutur memiliki tujuan dan maksud tertentu dari infromasi yang disampaikan. 
Pemakaian Akrolek pada Tindak Tutur...

Pernyataan yang diberikan oleh narasumber merupakan bentuk informasi yang harus didengar oleh banyak orang.

Narasumber: "Nah makanya Kenapa dibikin hukum undang-undangnya kalau kalau kalau tolak ukur tidak ada yang tahu cuman Tuhan kita nih memperebutkan apa gitu loh kalau untuk hoax Okelah gue masih setuju"

Undang-undang dibuat untuk dipatuhi dan ditaati maksud dari setiap pasalnya. Jika sudah terdapat undangundang namun, tidak mengerti isi dan maksud yang diinginkan maka, itu akan menjerumuskan kita ke dalam permasalahan. Bagi seorang yang bekerja di public figure harus mengerti akan hal ini.

Pada penelitian sebelumnya oleh Padmi (2017) dengan hasil penelitian fungsi asertif, yaitu menyampaikan sesuatu dan menunjukkan kebenaran dari proposisi dan pernyataan yang dibuat. Karena ini, akan menjadi tolak ukur dan pencegahan agar tidak masuk ke dalam lubang yang digalinya sendiri. Dengan demikian, jika berani berkata maka harus dipertanggungjawabkan.

Hal ini tidak jauh berbeda dengan penelitian sebelumnya, pada penelitian saat ini juga ditemukan bahwa Penggunaan bahasa ekspresif adalah yang paling sopan dari semua bahasa. Oleh karena itu, keragaman bahasa ini dianggap paling berwibawa yaitu penggunaan akrolek dalam penelitian ini. Namun, dari segi kaidah bahasa tidak sesuai dengan bahasa Indonesia yang tepat.

Dalam setiap informasi yang dibagikan baiknya dicerna apakah akan menimbulkan masalah atau memberikan manfaat kepada orang lain. Setiap informasi yang didapat memiliki maksud dan tujuan tertentu. Hal ini sejalan dengan pendapat Prasasti \& Mujianto, (2020), bahwa tuturan memberitahukan adalah ungkapan yang berisi informasi yang ingin disampaikan penutur kepada mitra tutur.

Jadi jika sudah salah dalam bertutur maka harus menerima sanksi yang sesuai denga apa yang sudah menjadi perintah secara tertulis. Oleh karena itu, pendapat atau informasi yang ingin disampaikan harus memiliki kejelasan atau bukti nyata yang benar-benar sesuai dengan keadaan sebenarnya. Dalam setiap tuturan yang dihasilkan harus sesuai dengan maksud dan tujuan agar tidak salah dalam menerima atau memberi informasi. 


\section{Keterlibatan Narasumber}

Keterlibatan narasumber pada saat berinteraksi sangat diperlukan. Sehingga, dapat terjalin komunikasi antar dua arah.

Jika melihat dari tuturan yang diberikan oleh presenter, presenter menangkap penjelasan yang disampaikan oleh narasumber adalah terdapat dua sisi orang yaitu sebagai orang memposting sesuatu dan orang bereaksi akan suatu postingan. Kedua hal ini sangat berhubungan antara satu dengan yang lain. Jika terdapat orang yang membagikan unggahannya tentang kehidupannya di media sosial maka dia adalah orang yang memposting.

Presenter: "Kalau lu mengatakan menggunakan sosmed dengan bijak artinya di sini ada dua sisi dong Bro, ya dari dua sisi dong jadi orang yang ngepost dan orang yang bereaksi"

Narasumber: "Betul, dan nggak tidak adil kalau yang dihukum selalu orang yang bereaksi bukan orang yang nepost"

Kemudian, jika mengomentari unggahan seseorang di dalam media sosial, dia adalah orang yang beraksi akan suatu postingan. Setelah itu, narasumber juga menambahi serta merespon tanggapan presenter bahwa, tidak adil jika yang hanya dihukum adalah orang-orang yang bereaksi atas postingan atau unggahan yang dibagikan di media sosial sedangkan orang yang mengunggah tidak.

Penggunaan variasi bahasa akrolek sering digunakan oleh hampir semua kalangan karena terkesan lebih sederhana dan bergengsi dibandingkan dengan variasi bahasa lainnya.

Pada penelitian sebelumnya oleh Tanasy, (2019) yaitu sosiolek akrolek mempengaruhi eratnya hubungan antar anggota KOSEMA dari berbagai latar belakang sosial budaya. Penggunaan dialek yang peka secara sosial umumnya disukai oleh semua anggota karena dipandang lebih sopan dan hormat kepada pembicara dan pendengar, terutama anggota perempuan. Sedangkan pada penelitian ini ditemukan adanya lebih banyak keterlibatan narasumber yang terdapat dalam hubungan antara ciri variasi akrolek dengan tuturan asertif. Karena dari segi objek penelitian yang berbeda sehingga, ditemukkan adanya perbedaan hasil penelitian yang ditemukkan.

Penggunaan ciri tutur asertif cenderung menggunakan variasi tutur yang tajam. Tuturan seperti itu dimaksudkan untuk menimbulkan reaksi dan memberikan informasi faktual atau berdasarkan fakta. Penggunaan ungkapan dalam tuturan asertif terutama didasarkan 
pada penutur dari masyarakat kelas menengah.

\section{SIMPULAN}

Pada siniar di konten youtube Deddy Corbizier. Pemakaian akrolek antara presenter dan narasumber sangat terlihat pada tuturannya. Setiap ciri pola variasi akrolek, bentuk tuturan asertif serta hubungannya antara ciri variasi akrolek dan bentuk tuturan asertif digunakan dalam berkimunikasi.

Berdasarkan penelitian, presenter dan narasumber menggunakan ciri pola variasi akrolek, bentuk fungsi tuturan asertif serta saling berhubungan antara ciri variasi akrolek dan bentuk tuturan asertif. Hampir di setiap ketiga data yang dianalisis hanya beberapa data saja yang tidak diutumakan dalam bentuk fungsi asertif, yaitu pada bentuk asertif menyarankan hanya ditemukan pada data 1 dan data 2. Kemudian pada bentuk tuturan melaporkan hanya ditemukan pada data 1. Kecuali data yang disebutkan bentuk asertif dan hubungannya dengan akrolek ditemukan dalam setiap data.

Tindakan yang dilakukan tersebut merupakan aktivitas percakapan antara presenter dengan narasumber seperti: asertif menyatakan, asertif mengeluh, asertif menyarankan, asertif mengklaim, asertif membanggakan, asertif melaporkan, dan asertif memberitahukan. Temuan yang menarik dari penelitian ini adalah penggunaan bahasa Indonesia yang digabungkan dengan bahasa asing (bahasa Inggris), memiliki nilai bahasa yang tinggi. Maksud dari nilai bahasa yang tinggi adalah dikatakan begengsi dibandingkan dengan bahasa yang lain. Akan tetapi hal ini bertentangan dengan kaidah bahasa Indonesia yang tepat dan benar.

Dalam kegiatan percakapan, asertif adalah salah satu strategi yang dapat diukur presenter ketika berkomunikasi dengan orang-orang yang cerdas. karena itu, pada kegiatan berbicara banyak yang menerapkan direct speech dengan memberikan informasi, nasihat, mengungkapkan rasa bangga dan sedih.

\section{DAFTAR PUSTAKA}

Achsani, F., \& Indonesia, T. B. (2019). Aspek Moralitas dalam Anime Captain Tsubasa melalui Penggunaan Tindak Tutur Asertif dan Ekspresif. Lingua, 15(1), 2335 .

Arnaselis, I. (2017). Tindak Tutur Asertif dalam Roman Larasati Karya Proedya Ananta Toer dan Implikasinya. Jurnal Kata, 5(3), $1--12$.

Corbuzier, Deddy. (2021). Hayoo! Ketua KPI VS Gue, (online), 
https://www.youtube.com/watch?v $=\mathrm{tHHeMejktN4}$.

Corbuzier, Deddy. (2021). Coki Pardede, Tolong Gue Dicari UU ITE!!, (online), https://www.youtube.com/watch?v $=\mathrm{x} 7 \mathrm{CM} 8 \mathrm{P} 044 \mathrm{E}$.

Corbuzier, Deddy. (2021). Konspirasi Segitiga Dunia dan "Kopid" atau Halu!?, (online), https://www.youtube.com/watch?v $=\mathrm{E} 2 \mathrm{tz} 529 \mathrm{r} 4 \mathrm{u} 0$.

Hartati, Y. S. (2018). Tindak Tutur Asertif Dalam Gelar Wicara Mata Najwa Di Metro Tv. In Jurnal KATA (Vol. 2, Issue 2). https://doi.org/10.22216/jk.v2i2.31 51.

Hildana, Z. (2017). Tindak Tutur Ilokusi Representatif Dalam Komik Seratoes Ploes Aspirasi Karya Haryadhi: Sebuah Kajian Pragmatik. 2(2), 146-158. http://repository.unair.ac.id/27491/

Nuryani, L., Santoso, A. B., \& Puspitasari, D. (2018). Variasi Bahasa Pada Pementasan Drama Cipoa Dan Sidang Para Setan Mahasiswa Pendidikan Bahasa Dan Sastra Indonesia Tahun 2017. Widyabastra: Jurnal Ilmiah Pembelajaran Bahasa Dan Sastra Indonesia, 6(1), 62-75. https://bit.ly/3ge8WNm.

Padmi, D. (2017). Jurnal Ilmiah Pendidikan dan Pembelajaran PPs Universitas Pendidikan Ganesha ISSN 1858 - 4543. 1(1), 164-175.

Prasasti, B. W. D., \& Mujianto, G. (2020). Pemakaian Akrolek Pada
Tuturan Asertif Dalam Gelar Wicara Hitam Putih. Jurnalistrendi : Jurnal Linguistik, Sastra, Dan Pendidikan, 5(2), 147-164. https://doi.org/10.51673/jurnalistre ndi.v5i2.304.

Safriani, N., Mahmud, S., \& Iqbal, M. (2018). TINDAK TUTUR ASERTIF DALAM NOVEL PEREMPUAN TERPASUNG KARYA HANI NAQSHABANDI. Jurnal Ilmiah

Mahasiswa Jurusan PBSI, 3, 67-77.

SUHENDAR, N. (2016). RAGAM BAHASA DI KECAMATAN PAKISJAYA KABUPATEN KARAWANG (Kajian Sosiolinguistik). Lokabasa, 7(1), 53. https://doi.org/10.17509/jlb.v7i1.3 407.

Susilawati, \& Yunus. (2017). Variasi Bahasa dalam Novel Peyempuan Karya @Peyem. Bastra (Bahasa Dan Sastra), 1(4), 1-14. http://ojs.uho.ac.id/index.php/BAS TRA/article/view/2388/1731.

Tanasy, N. (2019). Varian Bahasa dan Kohesi Sosial : Studi Kasus Komunitas KOSEMA di Kedai Kita Makassar. Jurnal Emik, 2(1).

Tidar, U., Kapten, J., No, S., \& Tengah, J. (2020). Tindak Tutur Asertif dan Formula Materi Ajar. 3(2010), 112.

Wirga, E. W. (2016). Content Analysis on Youtube Social Media to Support Political Campaign Strategies. Jurnal Ilmiah Informatika Dan Komputer, 21(100), 14-26. https://ejournal.gunadarma.ac.id/in dex.php/infokom/article/view/171 6. 